\title{
PENERAPAN SMS GATEWAY PADA SISTEM INFORMASI BOOKING SERVICE MOTOR DI CM JAYA MOTOR KUDUS
}

\author{
Zulfa Himmatul Ulya ${ }^{l}$, Noor Latifah ${ }^{2}$, Supriyono ${ }^{3}$ \\ 1,2,3 Fakultas Teknik, Program Studi Sistem Informasi, Universitas Muria Kudus
}

\section{Article Info:}

Dikirim: 26 Desember 2020

Direvisi: 28 Desember 2020

Diterima: 30 Desember 2020

Tersedia Online: 31 Desember 2020

Penulis Korespondensi:

Zulfa Himmatul Ulya

Fakultas Teknik, Program Studi

Sistem Informasi, Universitas Muria

Kudus,

Email: 201653052@std.umk.ac.id

\begin{abstract}
Abstrak: CM Jaya Motor adalah penyedia jasa perawatan sepeda motor honda. Sistem informasi booking service motor pada CM Jaya motor dirancang dan dibangun untuk tujuan mempermudah pelanggan dalam melakukan pemesanan service motor dengan tidak membuang banyak waktu. Penerapan SMS Gateway pada system informasi booking service motor membantu memberikan informasi mengenai waktu service motor serta pelanggan akan mendapatkan notifikasi jadwal service berkala. Metode Pengembangan system menggunakan waterfall yang dimulai dari requirement, Desain, Implementation, Integration dan testing, serta operation dan maintenance. Hasil dari penelitian ini yaitu suatu system informasi booking service motor dengan menerapkan SMS Gateway.
\end{abstract}

Kata kunci: system; booking service; SMS gateway.

\begin{abstract}
CM Jaya Motor is a Honda motorcycle maintenance service provider. The motorbike service booking information system at CM Jaya motorbike is designed and built for the purpose of making it easier for customers to order motorbike service without wasting a lot of time. The application of the SMS Gateway in the motorbike service booking information system helps provide information about motorbike service times and customers will get periodic service schedule notifications. The system development method uses a waterfall starting from requirements, design, implementation, integration and testing, as well as operation and maintenance. The result of this research is a motorbike booking service information system by implementing the SMS Gateway.
\end{abstract}

Keywords: system; booking service; SMS gateway. 


\section{PENDAHULUAN}

Sistem informasi saat ini merupakan kebutuhan yang sangat dibutuhkan oleh hampir semua bidang usaha, hal ini merupakan salah satu dampak dari perkembangan teknologi yang sangat pesat dan cepat perkembangannya. Dengan mengikuti perkembangan teknologi terutama teknologi informasi bisa mempermudah dan mempercepat waktu dalam melakukan suatu proses. Proses yang dilakukan dengan waktu yang lebih singkat dan mudah akan bisa menarik pelanggan serta mempengaruhi tingkat kepuasan pelanggan. Bidang usaha otomotif juga merupakan salah satu usaha yang bisa menerapkan perkembangan teknologi informasi dengan tujuan untuk meningkatkan pelayanan kepada pelanggan dengan lebih baik.Sistem kerja pada bidang usaha otomatif dalam hal ini bengkel yang masih manual pada reservasi servis mobil yang masih mengharuskan pelanggan untuk datang langsung ke bengkel, sehingga pelanggan tidak dapat mengetahui jika bengkel mobil tersebut sudah penuh dan tidak dapat melayani pelanggan[1].

Teknologi informasi pada bidang usaha otomotif bisa diterapkan pada bagian pelayananan jasa perawatan motor. Salah satu contoh penerapan teknologi informasi yaitu sistem informasi booking service motor yang bisa memudahkan dalam hal pemesanan serta mempersingkat waktu menunggu karena pelanggan tidak perlu waktu untuk antri dan datang ketempat waktu melakukan pemesanan. Saat ini banyak penyedia layanan reservasi service pada bengkel namun dilakukan secara manual dengan cara pelanggan harus datang langsung ke bengkel maupun melalui telepon dan SMS, setelah itu pihak bengkel mencatat nama pelanggan dan urutan reservasi pada sebuah buku. Hal ini menjadikan suatu masalah ketika jumlah antrian pelanggan cukup banyak, sehingga bengkel tidak dapat melayani semua pelanggan tersebut. Pencatatan secara manual juga sangat menyulitkan pihak bengkel ketika harus memberikan sebuah informasi kepada pelanggan perihal jadwal service[2]. Penggunaan transaksi online berbasis web sudah diterapkan diberbagai bidang dalam dunia bisnis. Kemudahan mengakses internet sekarang ini dapat dikatakan bahwa internet sangat bermanfaat dan menguntungkan[3].

Minat pelanggan sangat dipengaruhi oleh tingkat kepuasan terhadap pelayanan yang diberikan oleh bidang usaha pelayanan. Semakin baik pelayanannya, mudah dan tidak memakan banyak waktu maka akan semakin diminati oleh banyak orang. CM jaya motor merupakan usaha di bidang otomotif yaitu berupa bengkel penyedia jasa service motor merk honda di Jl. Sunan Kudus No.100, Kudus, Demaan, Kudus. CM jaya motor memiliki banyak pelanggan. Service motor dilakukan dengan cara pelanggan masih harus datang ke bengkel untuk antri mendaftar dan medapatkan nomor antrian serta pelanggan harus menunggu nomor antrian dipanggil. Sehingga membutuhkan waktu yang cukup lama jika pelanggan yang antri banyak. Untuk mempertahankan minat pelanggan perlu dirancang dan dibangun sebuah sistem informasi yang nantinya bisa meningkatkan kepuasan pelanggan terhadap pelayanan yang diberikan oleh CM Jaya Motor.

Aplikasi Sistem Informasi servis sepeda motor di buat untuk memperbaiki sistem manual yang telah ada menjadi terkomputerisasi sehingga bisa diakes melalui desktop serta dapat memberikan informasi servis secara lengkap dan efisien yang disimpan dalam sebuah database server [4]. Sistem informasi booking service ini akan mempermudah pelanggan dalam melakukan pendaftaran service motor tanpa harus datang ke tempat dan antri menunggu lama sampai dipanggil nomor antriannya. Dengan adanya program aplikasi Sistem Informasi Booking Service ini diharapkan dapat membantu pelanggan agar lebih mudah mendapat informasi dan melakukan booking service secara online[5]. Pada sistem ini akan diterapkan sms gateway untuk bisa memberikan informasi mengenai jadwal service berkala.

Berdasarkan permasalahan yang diuraikan diatas, maka dibutuhkan suatu sistem informasi booking service motor dengan memanfaatkan sms gateway yang akan membantu mempermudah bengkel CM Jaya Motor dalam hal pelayanan terhadap pelanggan pada saat melakukan booking service motor tanpa harus datang ke bengkel sebelum waktunya dan menunggu lama. Penerapan SMS Gateway digunakan untuk menyampaikan informasi mengenai nomor antrian dan jam datang ke bengkel serta memberikan informasi mengenai jadwal service berkala berikutnya. Sistem informasi booking service ini juga menyediakan informasi mengenai estimasi biaya yang harus dibayar nantinya.

\section{METODOLOGI PENELITIAN}

Proses yang sangat penting dalam pembangunan system yaitu adalah metode pengembangan system. Dalam pembuatan system ini menggunakan metode pengembangan sistem waterfall yang menyediakan pendekatan alur hidup perangkat lunak secara sekuensial dimulai dari analisis, desain, pengodean, pengujian dan tahap pendukung (support)[6].

Tahapan dari pengembangan sistem dalam metode waterfall antara lain :

a) Analisa Kebutuhan Perangkat Lunak

Tahap ini dilakukan Analisa mengenai spesifikasi-spesifikasi kebutuhan perangkat lunak untuk bisa diketahui dan dipahami kebutuhan user.

b) Desain Perangkat Lunak

Tahap ini merupakan tahap pembuatan program perangkat lunak didalmnya termasuk struktru data, desain user interface, procedure pengkodean, arsitektur perangkat lunak. Pada tahap ini desain perangkat lunak didokumentasikan diantaranya yaitu : Flow of Document, Unified Modelling Language dan desain untuk basisdatanya yang didokumentasikan dalam diagram - ER

c) Pembuatan Kode Program

Desain atau perancangan perangkat lunak yang sudah dibuat harus diterjemahkan ke dalam program perangkat lunak. Hasil dari tahap ini adalah program komputer sesuai dengan desain yang telah dibuat pada tahap desain.

d) Pengujian 
Tahap ini memastikan bawah semua bagian system sudah dilakukan pengujian supaya dapat meminimalkan kesalahan yang dilakukan secara tidak sengaja dan memastikan output sudah sesuai dengan yang diharapkan pengguna. Pengujian Blackbox digunakan pada tahap ini.

e) Pendukung atau Pemeliharaan

Pada tahap terakhir dalam Metode Waterfall, perangkat lunak yang sudah jadi dioperasikan pengguna dan dilakukan pemeliharaan. Pemeliharaan memungkinkan pengembang untuk melakukan perbaikan atas kesalahan yang tidak terdeteksi pada tahap-tahap sebelumnya. Pemeliharaan meliputi perbaikan kesalaha, perabikan implementasi unit sistem, dan peningkatan dan penyesuaian sistem sesuai dengan kebutuhan.

\section{HASIL DAN PEMBAHASAN}

\subsection{Analisa Sistem Berjalan}

Analisa sistem yang sedang berjalan (sistem lama) digambarkan dalam Flow Of Diagram

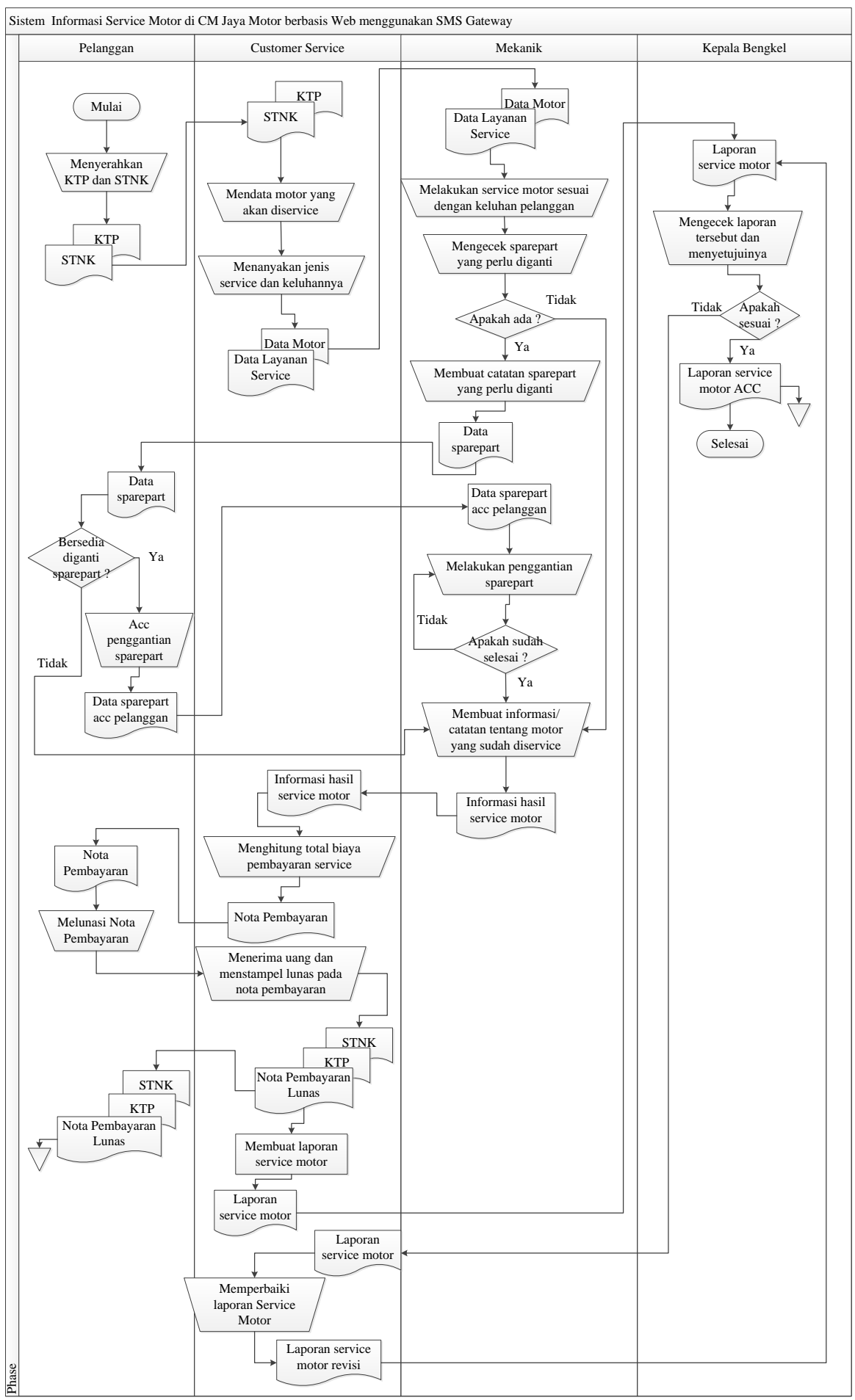

Gambar 1. FOD Booking Service Motor di CM Jaya Kudus 


\subsection{Analisa Kebutuhan Data dan Informasi}

Kebutuhan data dan informasi perlu dianalisa dengan baik supaya data yang diinput dan dikelola bisa menghasilkan informasi sesuai yang dibutuhkan.

Analisa data dan informasi untuk system booking service pada CM Jaya Motor kudus dengan menggunakan SMS Gateway yaitu :

a) Data

Data yang dibutuhkan di system ini adalah :
1) Data Registrasi
2) Data Motor
3) Data Sparepart
4) Data Pegawai (Mekanik)
5) Data Layanan Service
6) Data Pemesanan Service
7) Data Blacklist Pelanggan

b) Informasi
1) Informasi waktu service
2) Informasi jadwal service berkala
3) Laporan service pelanggan.

\subsection{Analisa Aktor Sistem}

Aktor system pada system booking service motor dengan menggunakan sms gateway diantaranya :

a) Customer Service (CS)

Customer service ini yang akan melakukan pengelolaan master data seperti data pegawai (mekanik), mengelola data sparepart, data registrasi serta mengelola data transaksi booking service motor.

b) Pimpinan/Kepala Bengkel

Pimpinan bengkel bisa melihat dan melakukan pengecekan laporan-laporan yang dikelola oleh customer service.

c) Pelanggan

Pelanggan dalam system ini bisa mengakses system untuk melakukan booking service serta dapat memperoleh informasi jadwal service berkala.

\subsection{Analisa Perancangan Sistem}

a) Diagram Sistem Use Case Sistem Informasi booking service motor pada CM Jaya Motor Kudus dengan sms gateway Diagram usecase system bisa memebrikan gambaran mengenai proses yang akan dilakukan di dalam system dan siapa saja yang terlibat di dalamnya. Diagram system usecase system yang akan dibuat bisa dilihat pada gambar 2 berikut.

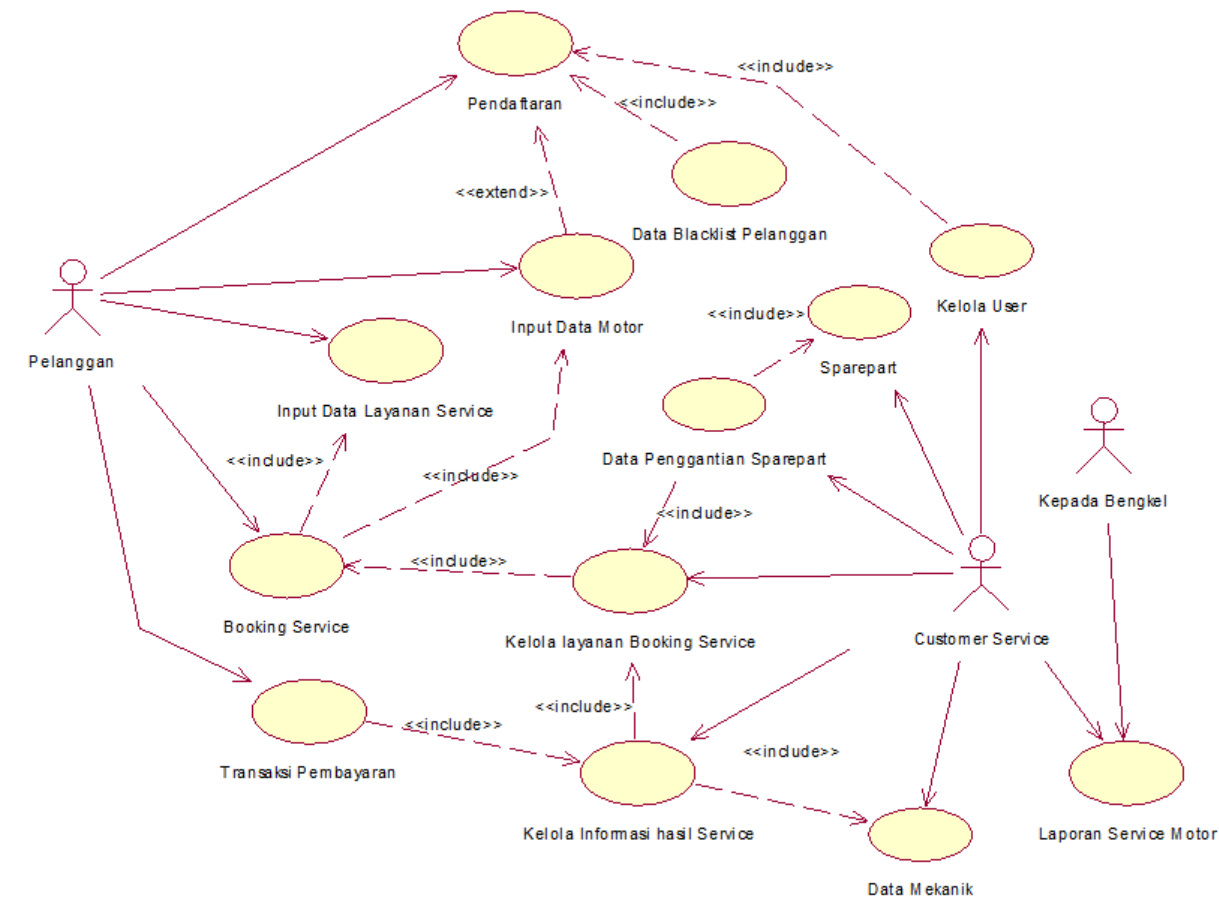

Gambar 2. Diagram Sistem Use Case Service Motor pada CM Jaya Motor Kudus dengan SMS Gateway 
b) Diagram Kelas

Diagram kelas penerapan sms gateway pada system informasi booking service bisa dilihat seperti pada gambar 3.

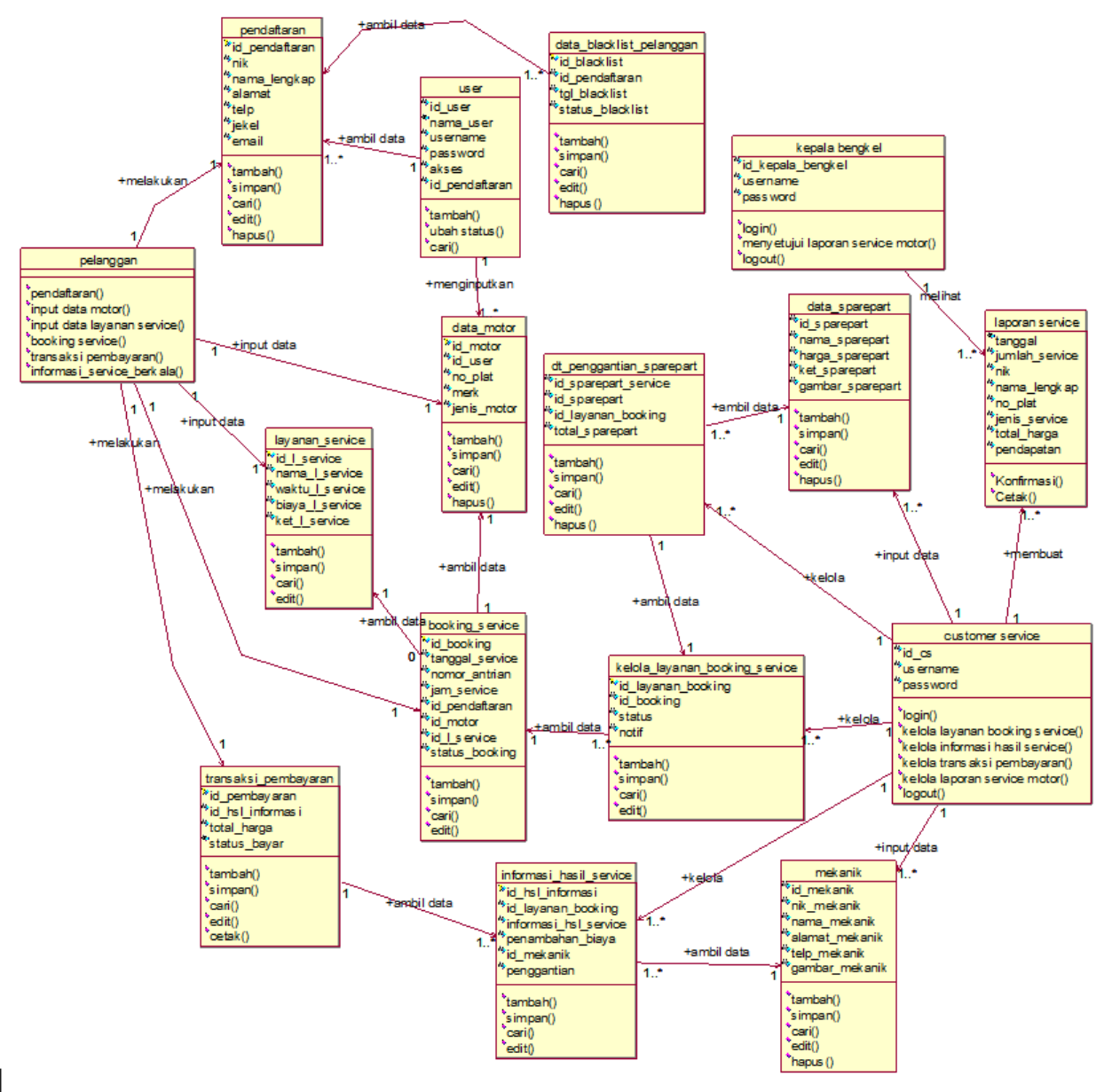

Gambar 3. Diagram Kelas Penerapan Sms Gateway pada Sistem Informasi Booking Service Pada CM Jaya Motor Kudus

\subsection{Perancangan Database}

a) Entity Relationship Diagram

Entity Relationship Diagram (ERD) merupakan diagram yang digunakan untuk merancang suatu basis data, untuk memperlihatkan hubungan atau relasi antar entitas atau objek yang terlihat beserta atributnya. Pada penerapan sms gateway pada system informasi booking service pada CM Jaya Motor Kudus bisa dilihat pada gambar 4. 


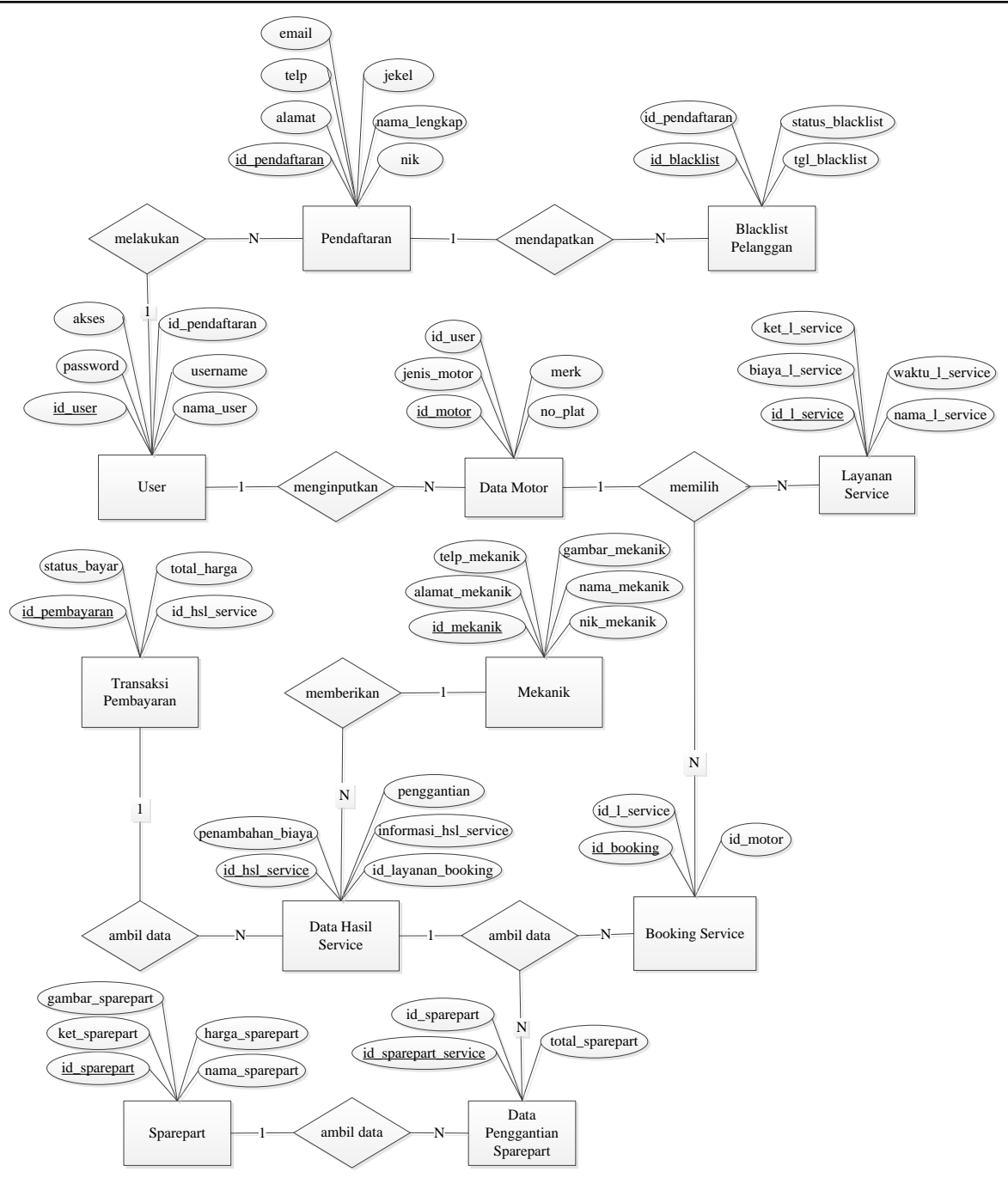

Gambar 4. Entity Relationship Diagram Penerapan SMS Gateway pada Sistem Informasi Booking Service Motor pada CM Jaya Motor Kudus

b) Relasi Tabel

Relasi tabel yang terbentuk pada database untuk pembuatan sistem informasi service motor di CM Jaya Motor berbasis web menggunakan sms gateway dapat dilihat pada gambar 5 berikut.

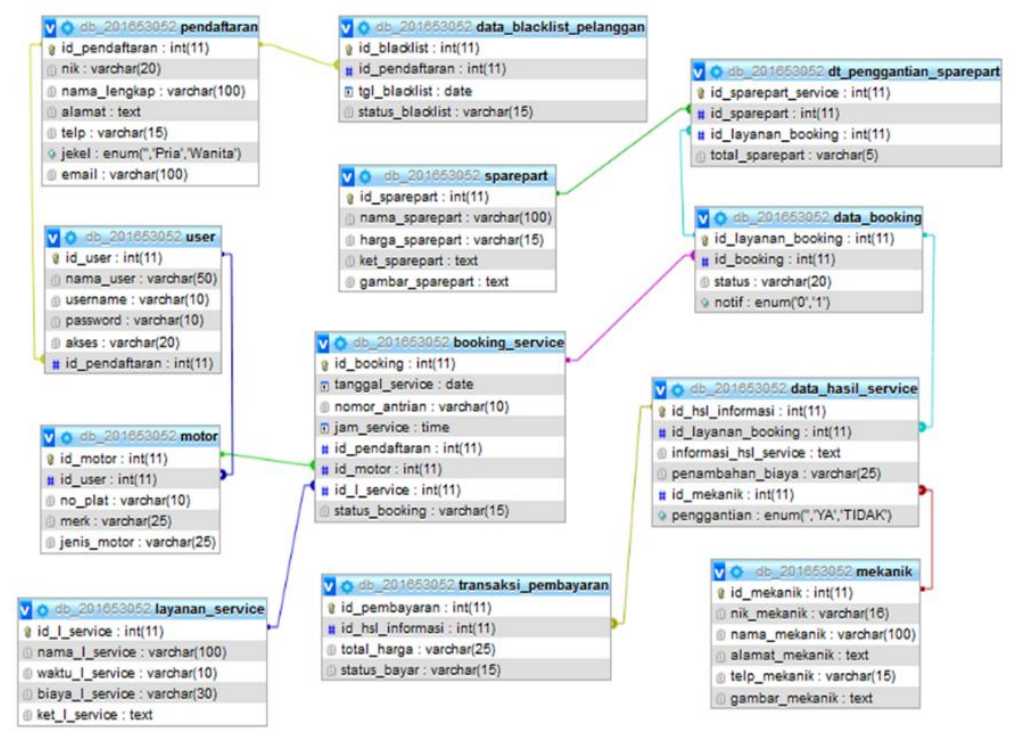

Gambar 5. Relasi Tabel Penerapan SMS Gateway pada Sistem Informasi Booking Service Motor pada CM Jaya Motor Kudus 


\subsection{Implementation}

a) Halaman Login

Halaman ini merupakan halaman login yang membedakan hak akses antara user atau pemakai system. Untuk bisa mendapatkan username sama password pengguna system harus melakukan registrasi terlebih dahulu.

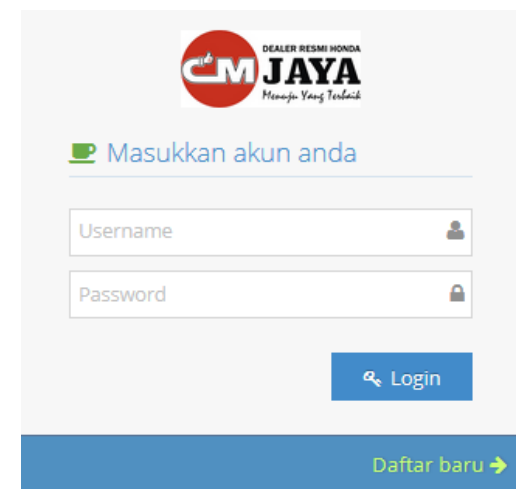

\section{Gambar 6. Halaman Login}

b) Halaman Registrasi Pelanggan

Halaman ini bisa diakses oleh semua user yang nantinya Ketika mengisi data dihalaman ini akan bisa mendapatkan username dan password yang digunakan untuk pemesanan booking service motor.

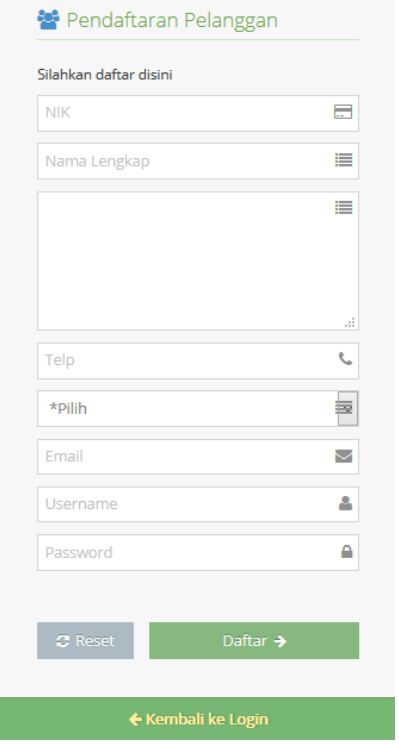

\section{Gambar 7. Halaman Pendaftaran Pelanggan}

c) Halaman Daftar Kendaraan

Booking service motor bisa diproses jika pengguna melakukan input data kendaraan pada halaman daftar kendaraan.

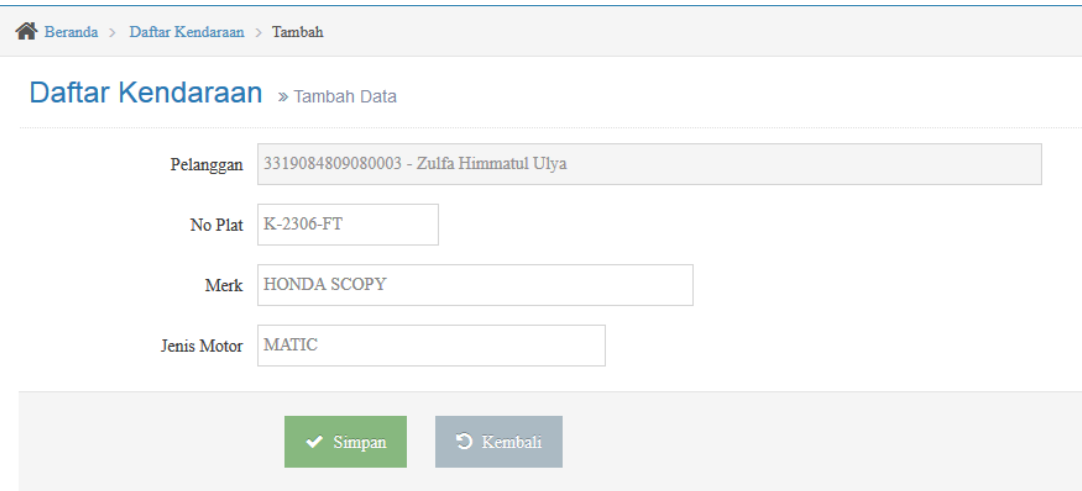

Gambar 8. Halaman Daftar Kendaraan 
d) Halaman Tambah Layanan Service Jenis layanan service bisa dipilih oleh pelanggan pada sistem sesuai dengan kebutuhan pelanggan. Halaman tambah layanan service bisa dilihat pada gambar 9 .

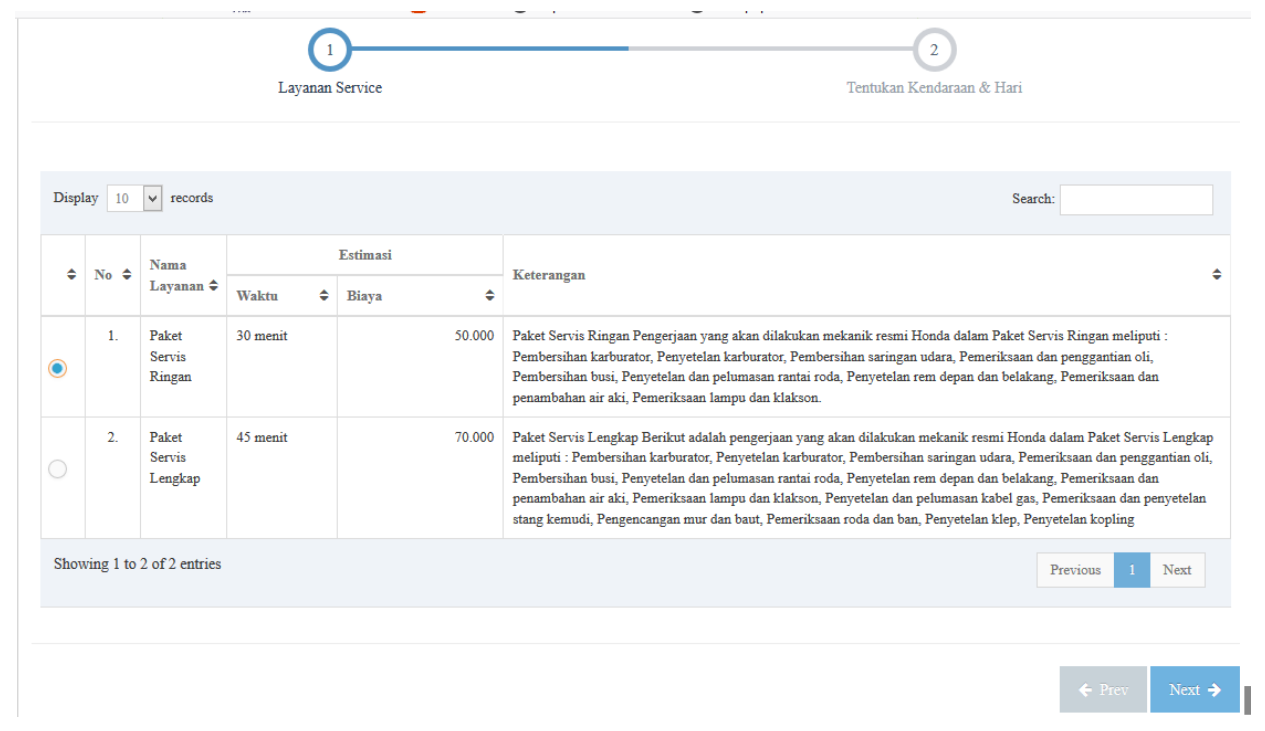

Gambar 9. Halaman Tambah Jenis Layanan Service

e) Halaman Tambah Daftar Booking Service

Pelanggan bisa melakukan pendaftaran pemesanan waktu service dengan menentukan tanggal yang diinginkan. Halaman untuk pemesanan waktu service bisa di lihat pada gambar 10.

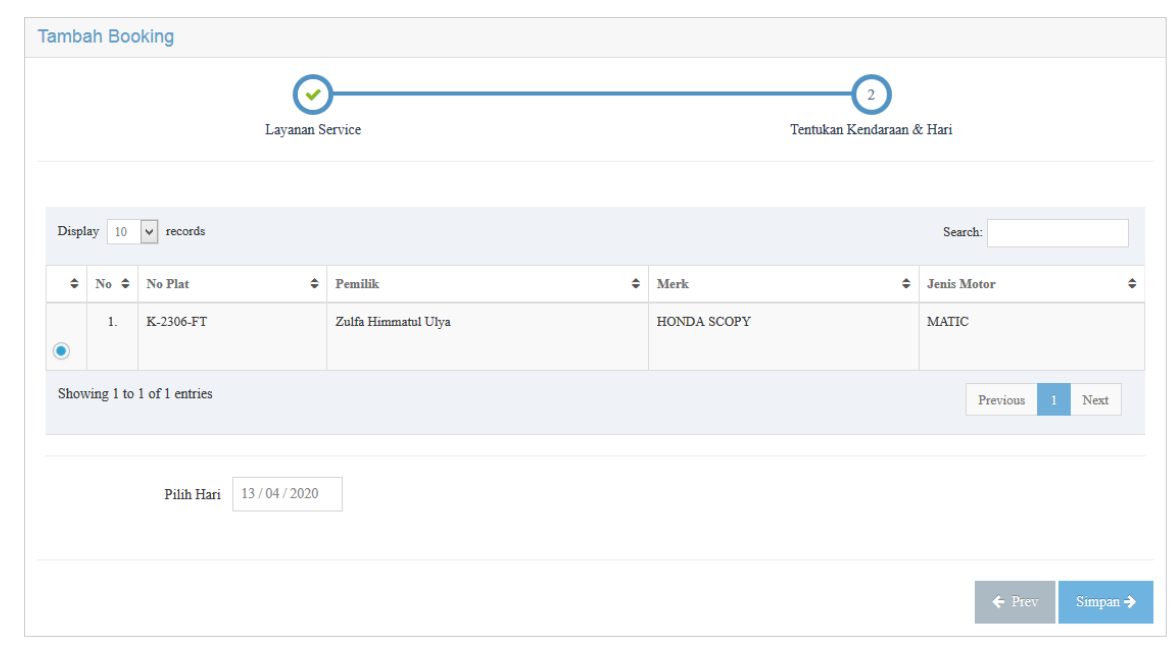

Gambar 10. Halaman Tambah Daftar Booking Service Penerapan 
f) SMS Notifikasi Booking Service motor

Pelanggan yang sudah melakukan pendaftaran pemesanan service motornya akan mendapatkan SMS Notifikasi.

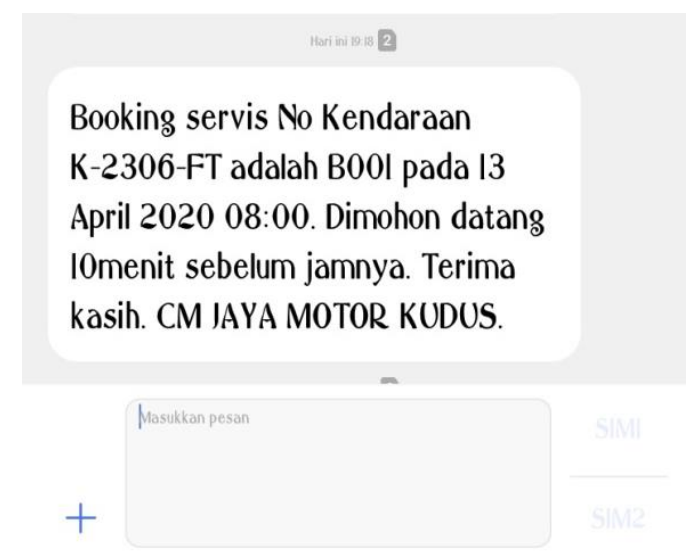

\section{Gambar 11. SMS Notifikasi Booking Service}

g) Beranda Utama Customer Service

Pelanggan Ketika mengakses system ini maka pertama kali akan masuk ke halaman beranda utama seperti pada gambar 12 .

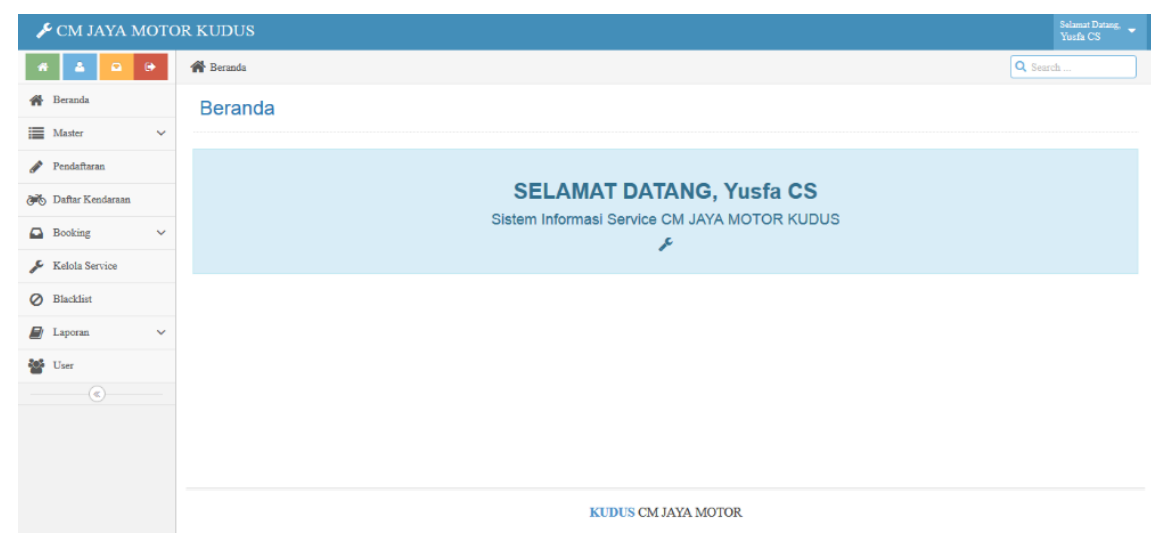

Gambar 12. Halaman Utama Customer Service Penerapan SMS Gateway

h) Halaman Kelola Layanan Booking Service

Pengelolaan data pemesanan service setiap harinya akan dikelola oleh customer service. Halaman Kelola layanan bisa dilihat pada gamar 13 .

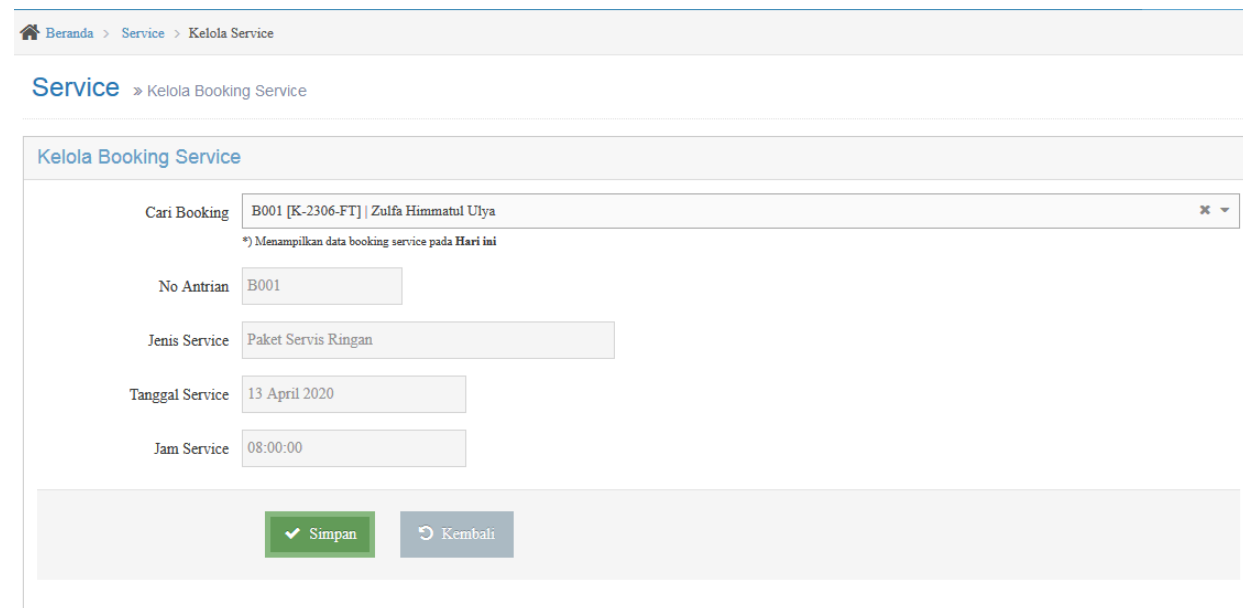

Gambar 13. Halaman Kelola Layanan Booking Service 
i) Halaman Kelola Informasi Hasil Service

Setelah service dilakukan maka CS akan menginputkan hasil service dan menginformasikan hasil service kepada pelanggan,Jika terdapat sparepart yang harus diganti makan akan diinformasikan terlebih kepada pelanggan untuk menyetujui atatu tidak. halaman Kelola hasil service bisa dilihat pada gambar 14, 15, 16.

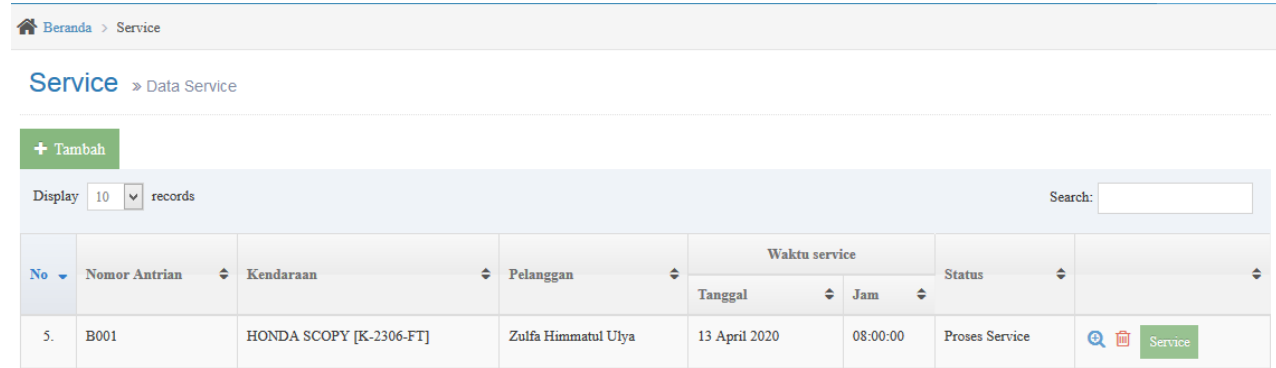

Gambar 14. Halaman Kelola Informasi Hasil Service

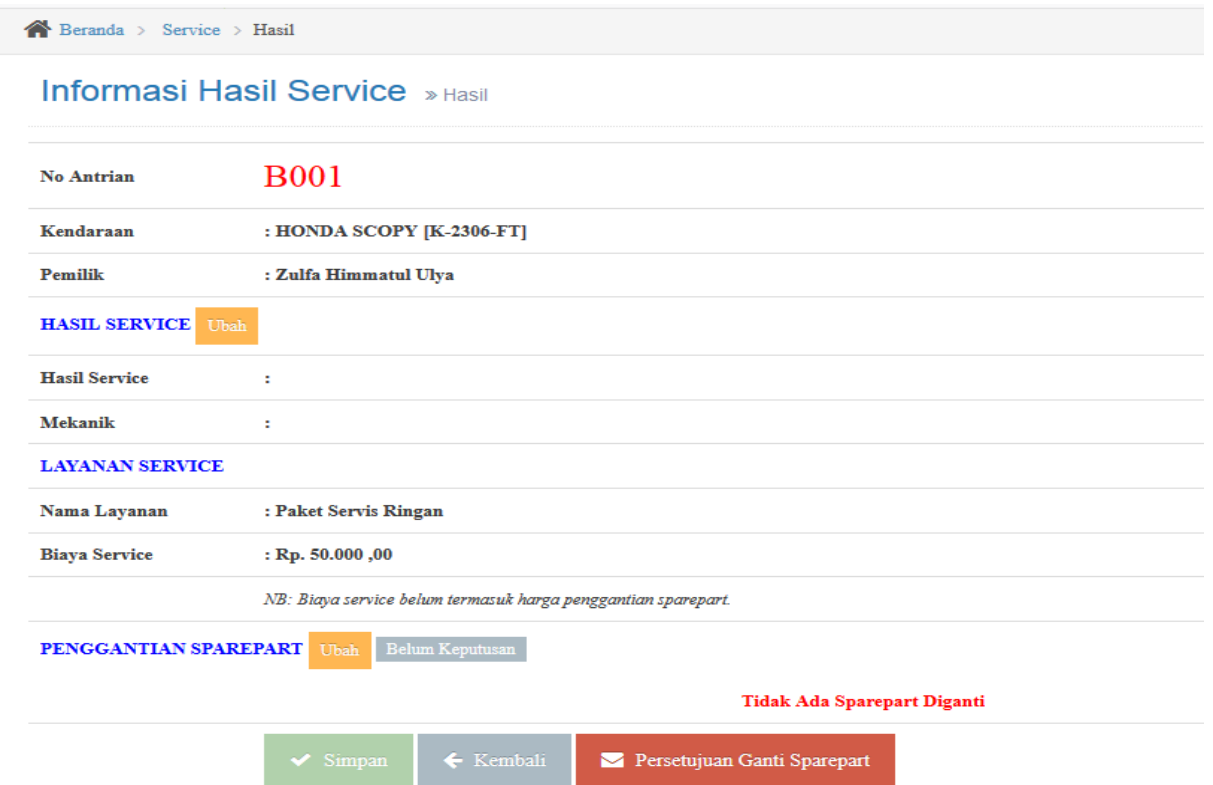

Gambar 15. Halaman Persetujuan Penggantian Sparepart

202

Zulia Himmatul Ulya,kendaraan

K-2306-FT ada ganti sparepart dgn biaya 45.000. Bila setuju balas

YA(spasi)K-2306-FT, bila tidak

balas TIDAK(spasi)K-2306-FT.CM

IA

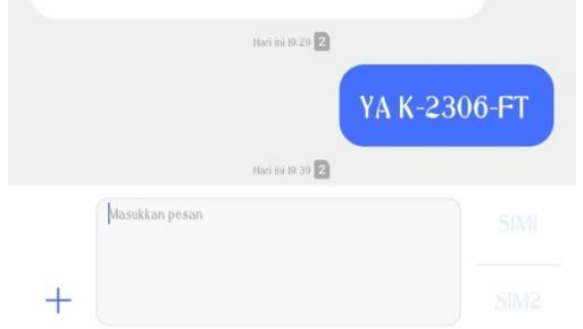

Gambar 16. SMS notifikasi Pergantian Sparepart 
j) Halaman Tambah Transaksi Pembayaran

Transaksi pembayaran bisa dilihat pada gambar18.

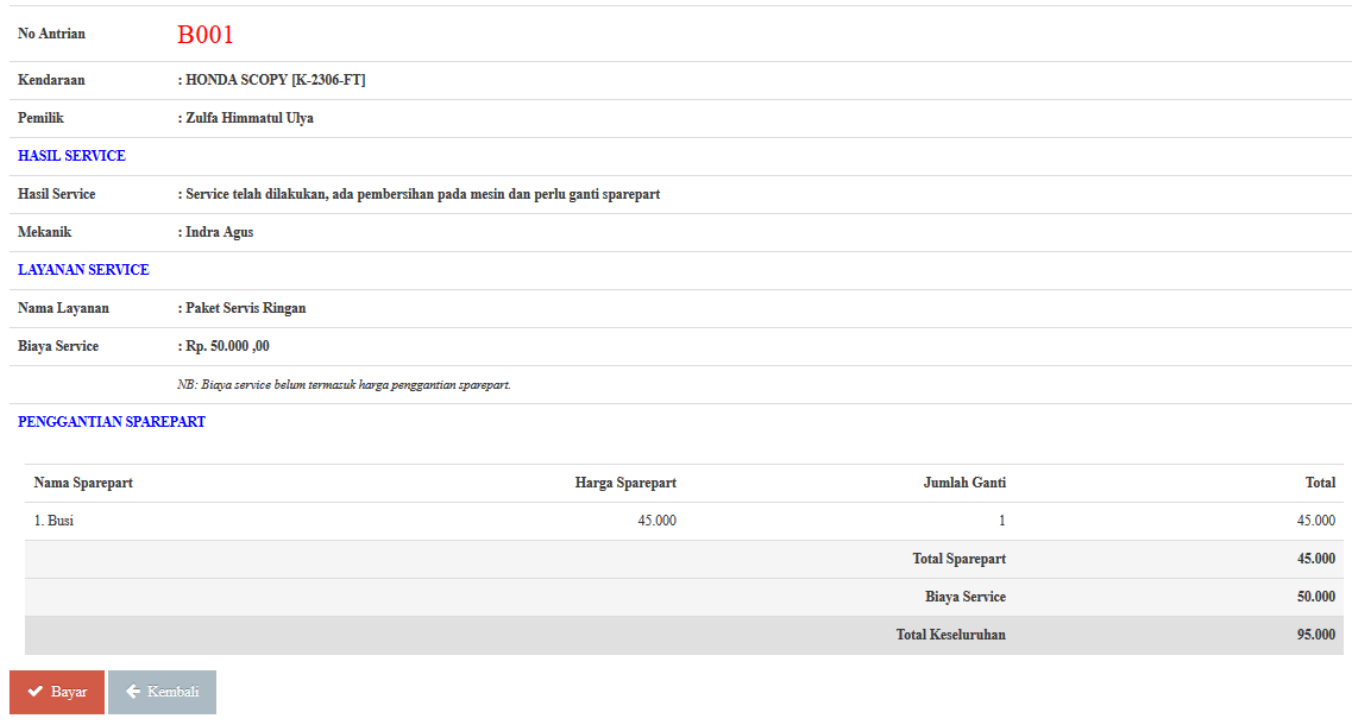

Gambar 18. Halaman Transaksi Pembayaran

k) Output : Nota Transaksi Pembayaran

J1. Sunan Kudus No.100, Kudus, Demaan, Kec. Kota Kudus, Kabupaten Kudus
Jawa Tengah 59313

13 April 2020

Customer Service

\section{Gambar 19. Nota pembayaran}

1) Informasi Service Berkala

Notifikasi kepada Pelanggan untuk melakukan service secara berkala 3 hari sebelum jadwalnya.

Kendaraan anda dengan nomor kendaraan K-2306-FT ada jadwal servis berkala besok pada $0 \mathrm{l}$ Juni 2020. Silahkan lakukan booking service pada website. CM IAYA MOTOR

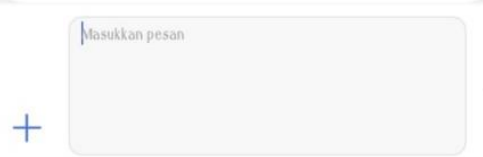

Gambar 20. SMS Notifikasi Informasi Service Berkala 
m) Laporan Service Motor Laporan service motor bisa dilihat pada gambar 21

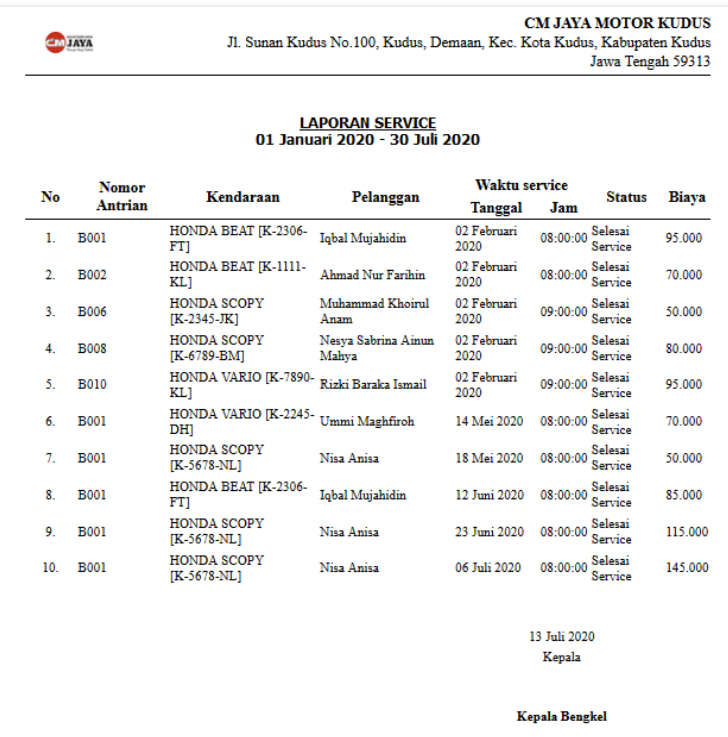

Gambar 21. Halaman Laporan Service Motor

\section{KESIMPULAN}

Kesimpulan setelah dilakukan perancangan dan pembuatan sistem booking service pada CM Jaya Motor kudus dengan menerapkan SMS Gateway yaitu :

a) Sistem informasi booking service motor pada CM Jaya motor Kudus dengan fiture sms gateway memudahkan pelanggan dalam membooking service sebelum hari service dan pelanggan tidak perlu menunggu lama ketika service motor.

b) Penerapan sms gateway pada sistem booking service motor ini membantu menyediakan informasi mengenai jadwal service berkala berikutnya.

c) Sistem informasi booking service motor di CM JAYA MOTOR ini dapat membantu meningkatkan kepuasan pelanggan terhadap pelayanan yang diberikan seperti tidak perlu membuang banyak waktu hanya untuk menunggu motornya diservice.

\section{DAFTAR PUSTAKA}

[1] Reza Fajar Nugroho, T. A. (2016). "Perancangan Dan Implementasi Sistem Reservasi Servis Mobil Berbasis Website". Fakultas Ilmu Terapan, Universitas Telkom, Bandung, ISSN : 2442-5826.

[2] Gusti Ngurah A.W, M. A. (2017). "Rancang Bangun Aplikasi Reservasi Service Untuk Bengkel Sepeda Motor Berbasis Web”. Program Studi Teknik Elektro, Fakultas Teknik, Universitas Udayana.

[3] Megantoro, D. N. (2018). "Perancangan Model Booking Service Untuk Meningkatkan Customer Relationship Management”. Skripsi. Jurusan Teknik Industri Fakultas Teknologi Industri.

[4] Wahyudi, A. (2017). "Sistem Informasi Service Sepeda Motor pada Yamaha Mataram Sakti Mayong Jepara Berbasis Web”. Skripsi. Program Studi Sistem Informasi, Fakultas Teknik, Universitas Muria Kudus.

[5] Prasetyo, M. L. (2017). "Pengembangan Sistem Informasi Booking Service Motor Honda Pada Pt. Pacific Motor Ii Bekasi Berbasis Web”. Manajemen Informatika, Program Diploma 3 AMIK BSI Bekasi, ISSN : 2615-3645.

[6] M.Shalahuddin, R. A. (2018). Rekayasa Perangkat Lunak (Terstruktur dan Berorientasi Objek). Bandung: Informatika Bandung. 